DINAMIKA ILMU

Vol. 19 No. 2, 2019

P-ISSN: 1411-3031; E-ISSN: 2442-9651

doi: http://doi.org/10.21093/di.v19i2.1746

\title{
The Role of the Family in Internalizing Islamic Values
}

\author{
Afiful Ikhwan \\ Universitas Mubammadiyah Ponorogo \\ afifulikhwan@gmail.com \\ Oktio Frenki Biantoro \\ Universitas Islam Negeri (UIN) Maulana Malik Ibrabim Malang \\ myslabung@gmail.com \\ Ali Rohmad \\ Institut Agama Islam Negeri (LAIN) Tulungagung \\ alirohmad@iain-tulungagung.ac.id
}

\begin{abstract}
Education is a conscious and planned effort that is applied to shape the character of a child who is characteristically and adheres to Islamic values in daily life. Thus the role of the family in providing education to children is very urgent to be applied in today's society which experiences moral decadence. The concept of religious values in children developed is the values of rabbaniyah and values of insanity. The steps of family involvement in internalizing ethical values in children are carried out through the stages of value transformation, value transactions, value internalization, and transcendalization of benefits by developing aspects of knowing, doing, and being. The element of knowledge is done by giving insight to children about religious values. The point of doing is made by guiding children. The aspect of being is done by providing an example to children. The three processes are not only carried out in schools but also carried out in the family with the guidance of parents. Also, in the process develops the concept of moral (moral knowing), honest attitude (good feeling), and ethical behaviour (moral behaviour).
\end{abstract}

Keywords: family environment, internalization, Islamic values 


\section{A. Introduction}

This research comes from anxiety and aspirations for national education. Today, the problem of the nation's moral decline is increasing. The issue of moral decadence, rape, free sex, consuming alcohol or drugs, theft, murder, robbery, and even more astounding the existence of cases of tricky and sadistic gangsters to kill their victims (Suparman, 2014; Harian Kompas, 2015; Sulton, 2016; Abdi, 2018). Based on some of these problems as educator actors and parents have grave concerns.

Several aspects have triggered this issue to occur, for example (1) Adhering to the existence of specific political perspectives that lead to religious matters is each individual's business, not a partisan issue. Therefore, humans are not obedient to their Lord, and then their lives will obey their passions. (2) Environmental pollution starts from forest fires; wastes discharged into rivers or dissolution of humans in immorality which follow their desires (Hari, 2007). (3) Extinction of humans into the flow of the globalization era that results in someone loving the world, living extravagantly or royally, not having an attitude of empathy, greed, and spree to forget the future life (Muhaimin, 2016; Susanti, 2016).

Therefore, to obtain answers to these problems, the inculcation of religious values in schools and families becomes very important. Spiritual values are ethical values that cover the subject of worship, creed, and morals that guide someone who is manifested through daily life (Sahlan, 2010). In addition, religious values are values that exist in a person's soul based on Divine values (Sjarkawi, 2008; Huda \& Ikhwan, 2019).

Spiritual values have the aim to print the human soul to have the right attitude that is actualized in everyday life. Based on these objectives, ethical values also reinforce the goals of Islamic religious education, namely to increase one's faith, the level of student understanding, the deepening and implementation of Islamic spiritual teachings (Endang, 2010; Fadhil, 2018). Therefore, this process will form people who believe, devoted to God, and have good morals to themselves, family and society in general (Nasution, 2018).

The process of internalizing religious values actualized in schools requires some assistance from various parties, for example, support from family and community. This is due to the child's educational process, ideally taking place in three places of education that affect children's understanding (Sazali, 2017). The three areas are the school environment, family environment, and community environment. Children's education is not only carried out in schools but also carried out in the family or community environment or vice versa (Hasbullah, 2000; Dalmeri, 2018). But lately, the system adopted by national education has an impact there is a gap between the three educational settings. Therefore the role of the family in children's education is only as a person who looks for the cost of tuition for children.

Abdullah Nashih Ulwan confirmed that the role of the family in children's education is vital. Parental assistance to their children's education will have a good impact on the child's learning process. A child who experiences separation from his parents, then the child will undoubtedly learn through experience in himself also learn from the environment around him. Therefore, if the environment around him is right then the child will also be useful, conversely if the climate is around bad then the child will also go along to be wrong and worse will make the child kufur and heresy (Sukiyani \& Zamroni, 2014). Assistance provided by parents for children will create a pleasant environment in children's education.

This issue is certainly a concern for researchers to immediately get answers through a study. Therefore, this research was conducted in the Al-Kautsar Kindergarten in Ponorogo, 
East Java, Indonesia. Researchers chose the location because of a variety of strong considerations, including that the institution has efforts in strengthening religious values that involve families in the process of children's education.

Also, the Al-Kautsar Kindergarten in carrying out the educational process using student contact books. This book is a reference for parents in conducting the education process while at home. To equalize the ability of parents in performing education when at home, the teachers hold a meeting agenda held every month. This monthly agenda is a way to equip parents in home education and communication facilities if there are obstacles encountered in the home education process. Also, there is a WhatsApp (WA) group that is used in each class.

Departing from the context of the research, researchers are interested in examining the phenomena that occur to conduct this research. In addition to uncovering these problems, this research is expected to contribute both theoretically and practically and be able to add to the knowledge that is a reference in internalizing religious values in schools in general.

\section{B. Literature Review}

\section{Family Involvement in Children's Education}

The family has a significant role in children's education. This is because children spend a lot of time in the family. Ideally, children's education should have continuity in three places, namely the family environment, school environment, and community environment (Jufri, La Fua, \& Nurlila 2018). As the smallest social institution, the family has a role for children's education to create a safe environment, a comfortable atmosphere, and an atmosphere that is conducive to child growth (Ratnawati, Sarjana, \& Taman, 2016).

The family environment is the beginning of the process of interaction of children before he went to school or society. The role of the family in supporting children's education is enormous, especially as a motivator in encouraging the child. The family sets an example in the goodness of their children. In fostering character requires excellent communication between family and children. This is because the intensity of the time is more compared to other educational environments. Also, the family is the beginning of the child's life before a further level, so it is very influential on the child's success rate (Djaali, 2012).

Within the family, the environment is laid the foundations of a child's education to build on his or her best ability in the future to achieve family achievement (Fitriastuti, 2013). The external environment that gives a significant impact on children's development is the family environment (Dalyono, 2012). For children who have studied in school, this family environment has a substantial effect on children's learning and teaching activities. These impacts can be ethical or can have an adverse impact (Syah, 2010).

The role of the family in children's education is very much needed for children. This is due to several considerations, as follows:

a. The first institution for children is the family.

b. The person who excels in developing the child's psychological development is the family.

c. The task of meeting basic needs, both physically and spiritually, is family.

d. The intensity of the child's time is spent more on the family when compared to other places (Yusuf, 2011). 
In the view of Islam, the family environment is the first environment that plays a role in building the process of forming the character of children (Mansur, 2009). In a family, each individual has their respective duties. The task is as follows:

a. The father has a role to be through communication to direct the activities of children and organize children's lives (Dagun, 2002). Also, the father has an objective function so that education can run in full balance both physically and spiritually (Syawaluddin \& Iswari, 2014).

b. Mothers have a role as people taking care of the household, and if the husband's financial fulfilment is lacking, she can help earn a living for the family (Hidayati, 2000).

Children are tasked with working on their psychiatric roles according to the child's growth and development stage, both physically and mentally (Sukaimi, 2013). Parents must give love to their children. Also, children must help both people according to their abilities and be obedient to both parents and get an education for a better future (Nurmasari, Wahyono, \& Haryono, 2016).

\section{Stages of Internalizing Religious Values in Children}

The internalization of religious values in early childhood requires several steps that must be passed. Ahmad Tafsir asserted that internalization is an effort to instil knowledge (knowing), can do it (doing), into the human soul (being). Therefore there are levels in internalizing values up to the human soul (Supeni, 2015).

Muhaimin also emphasized that the steps to internalize religious values in early childhood are as follows:

a. Value transformation stage. At this stage, the teacher merely informs excellent and bad grades to students, which are merely verbal communication (Ikhwan \& Fauzi, 2018).

b. Value transaction stage, which is a stage of value education by way of two-way communication or interaction between students and teachers is reciprocal. In this stage not only presents information about good and bad values, but also is involved in carrying out and give examples of tangible practices, and students are asked to provide the same response, which is to accept and practice that value

c. Transinternalisation stage, which is more than just a transaction. In this stage, the teacher's appearance before the student is no longer a physical figure, but his mental attitude (personality). Likewise, students respond to the teacher not only their movements or physical appearance but their mental attitude and personality. Therefore, it can be said that in this internalization is the communication of two characters, each of which is actively involved (Mawardi, 2011).

In the internalization process that is associated with student coaching, there are three stages that occur, namely:

a. Value transformation stage: This stage is a process carried out by educators in informing ethical values and good grades. At this stage, only verbal communication occurs between the teacher and students. 
b. Value Transaction Stage: A stage of value education by conducting two-way communication or interaction between students and reciprocal educators.

c. The transinternalisation stage is far more profound than the transaction stage. At this stage not only is done by verbal communication but also mental attitude and personality. So at this stage, personality communication plays an active role (Mawardi, 2011).

Various religious values, according to Madjid, several ethical values must be instilled in children and educational activities which are the core of religious education. Among the fundamental values are Faith, Islam, Ihsan, Taqwa, Ikblas, Tawakkal, Gratitude, Forbearance (Madjid, 2000). There are several processes for internalizing religious values in students as follows (Madjid, 2000):

a. Indoctrination approach, which is an approach used by the educator to teach or instil learning material with an element of force to be mastered by the student.

b. Moral reasoning approach, which is an approach used by teachers to present material related to morals through logical reasons to make the right choice.

c. The forecasting concealment approach is the approach used by the teacher to invite students to find possible consequences of an action.

d. Value classification approach, which is an approach used by the teacher to invite students to find an action that contains elements of value (both positive and negative) and subsequently will be found values that should be done.

e. The ibrah and metal approach, which is an approach used by the teacher in presenting material with the intention that students can find stories and parables in an event, both that which has happened and that has not yet happened.

Learning objectives, according to Ahmad Tafsir, contains three main aspects, namely: knowing, doing, and being or in terms, commonly known as cognitive, psychomotor, and affective issues. Internalization is the achievement of the last element (being). Henceforth the author will describe these three aspects of learning objectives briefly.

a. Knowing (Knowing): In this first stage which is knowing (knowing) the task of the teacher is to get students to see a concept. In the religious field, for example, students are taught about the meaning of prayer, prayer terms and conditions, prayer procedures, things that cancel prayer, and so forth (Ikhwan, Fahriana, Musyarapah, Mukhlis Fahruddin, \& Jaelani, 2019). The teacher can use various methods such as; discussion, question and answer, and assignment (Ikhwan, 2015).

b. Ability to perform or do what he or she knows (Doing): The ability to perform or do what he or she knows is a teacher's task is to enable the student to practice it. To achieve this goal, a teacher can use demonstration methods or play a movie.

Become as he knows (being): At the stage of becoming as he knows (person) a student can do what he already knows is not because he was instructed or because the teacher assessed him (Tafsir, 2006; Putri, Agung, Negara, \& Kristiantari, 2017). Therefore, at this third stage, students already have good awareness. 


\section{Research Methodology}

This study uses an interpretive paradigm through a qualitative approach, a type of case study. Taking the location of this study, according to the authors, is unique from other sites because of the integration of the role of the family in internalizing Islamic values (Ikhwan, 2014). Data obtained from the Head of Madrasas, Teachers, Students, Guardians of Students and other parties involved, with data collection techniques using in-depth interviews, observation and documentation. The analytical tool used is the qualitative analysis model of Miles and Huberman data reduction, data display and verification. Checking the validity of the data using triangulation; credibility, transferability, dependability and confirmability. The focus of this research is the concept of religious values in children and the implementation of family involvement in the application of the internalization of ethical values in children.

\section{Findings and Discussion}

\section{The Concept of Religious Values in Children}

Based on research findings that show that the concept of religious values in children developed in Ponorogo Al-Kautsar Children's Park plays a vital role in shaping students' religious attitudes. The ethical values that are applied refer to the theories put forward by the Nurcholis Mosque. These values are the values of Rabbaniyah and Insaniyah. Rabbaniyah values are embodied in the activities of the benefits of faith and piety, Islamic values, courtesy, and gratitude. While insane amounts are represented in the activities of friendship values, brotherhood values, liberal values, select values, and the value of keeping the environment clean. Rabbinic values are religious values found in the Qur'an that are practised in the attitude of faith, loyalty, and justice (Waliko, 2007). This Rabbinic value has certain truths that are then embodied in everyday life. This is by the role of humans as leaders on earth that is to try to explain the function of religious values and apply them in everyday life (Mardliyah, Sunardi, \& Agung, 2018). Whereas human values are the basis for the implementation of ethical values derived from customs originating from ancestors that bind to the culprit. This value gets approval and continues to increase towards a more modern direction (Setiawan, 2013).

According to Nicholas, the Mosque states that in the teachings of Islam, there are two values, namely, rabbinic values and insane values. Rabbinic costs include faith, Islam, mercy, loyalty, sincerity, tawakal, gratitude, and patience. While crazy amounts are hospitality, brotherhood (fellowship), equality (breakfast), fair ('adl), good (busnudhan), humble (tawadhu'), exact (wafa'), chest (insyirab), officers, saving (qawamiyyab), benefactors (munafiq) (Madjid, 2013).

Based on this theory, then, in establishing forms of religious values must have values that are rabbinic and insane. This value should be developed in children's education as it is the basis of Islamic culture. The Rabbaniyah values applied in the Al-Kautsar Ponorogo Children's Park are the values of faith and piety, Islamic values, courtesy, and gratitude.

First, the value of faith and piety. The values of faith and piety are values of belief and are created in obedience to God. Also, this value is fundamental to religious behaviour. In carrying out these values of faith and devotion are created in the form of activities such as memorization (daily prayer, short letter, chosen hadith, and asmaul busna), recognition of the values of sunnah, strengthening of Islamic religious education, commemoration the great day of Islam, the learning of Iqra and the Qur'an. The value of faith is the starting point for the child to teach as it will influence the child's character (Nugroho, 2016). 
Second, the amount of Islam. Islamic values are values that guide Islamic teachings in the formation of religious values in schools. This value is taught so that students in schools can practice the teachings of Islam in their lives (Sidiq \& Ikhwan, 2018). The implementation of Islamic values in the Al-Kautsar Ponorogo Kindergarten is manifested in various activities such as ablution practice, prayer practice activities, zakat fitrah, ramadhan hut, and hajj rituals. Islamic Religious Education is an effort to develop the nature of diversity (religiosity) students to be better able to understand, live and practice the teachings of the Islamic religion (Wiwinda, 2016).

Third, the value of Ihsan. Ihsan value is an embodiment of the importance of faith and Islamic values that are applied in everyday life. Ihsan values are actualized through the virtues taught in Islam. The implementation of Ihsan values in the Al-Kautsar Ponorogo Kindergarten was manifested in various activities such as the folding of sarong and make competitions, famous pilgrimage, praying before and after the events, halaqah, istighosah, and recitation of prayers. Zakiyah Daradjat asserted that through the teachings of Islam in the form of guidance and care for students so that after finishing education they can understand, live and practice the teachings of Islam that have been believed as a whole, and make the teachings of that religion as a view of life, for the sake of safety and prosperity in the world and the hereafter (Firdaus, 2012).

Fourth, the value of gratitude. The amount of appreciation is the attitude of a person is showing the gift of God to his creatures for use by Islamic teachings. The position of the believer when favoured is that he is grateful to his Lord. Therefore, the application of this value of gratitude to the Al-Kautsar Ponorogo Children's Park was made possible through the activities of the school-sponsored activities. These values of gratitude are reinforced by the letter of Abraham verse 7 . From these verses can be understood when we are grateful, then God will add pleasure. But if kufr, it will get God's punishment. Therefore, the value of gratitude must be actualized in education in schools (Ikhwan, 2018b).

Fifth, the value of caring about environmental cleanliness. A clean school environment is a comfortable environment for the learning process for children. A child's concentration will be better than learning in a dirty environment. This is because psychologically a clean environment will make students more at ease when learning so that students' performance will also be better. The application of the value of maintaining environmental cleanliness in the Al-Kautsar Ponorogo Kindergarten is through community service activities to clean the school environment, maintain bathroom cleanliness, clean the mosque, and pick up garbage that is found and dispose of it in its place. The attitude of caring for the environment is the attitude and actions that always try to prevent damage to the surrounding natural environment, and develop efforts to repair the damage to nature that has already happened (Kementerian Pendidikan Nasional; Balitbang Pusat Kurikulum, 2010).

This is by the word of God contained in Al-Baqarah: 222. Based on that verse, it can be concluded that Allah SWT. Likes people who purify themselves. In this case, it can be related to the value of maintaining environmental hygiene which is carried out in both educational institutions, namely in the Al-Kautsar Ponorogo Kindergarten who instil these values in learning in schools.

Based on the above views on the concept of religious values in children developed in the Al-Kautsar Ponorogo Children's Park, it can be concluded that the form of spiritual values is rabbinic and insane. These values are based on the costs contained in the al-qur'an and alhadith, as well as the benefits of Islamic education. This concept of Islamic religious education 
is an embodiment of the servant's devotion to his Lord for victory (Ikhwan, 2018a). This is by the Qur'anic recommendation of An-Nur: 52. From that verse, obedience to God is essential because it will win. The victory meant in the poem is heaven. Obedience to God is a vertical relationship and willingness to the Apostle is a horizontal relationship.

Muhaimin stated that when viewed from the source, the value can be divided into two, namely spiritual value and human value. Moral value is the value of faith that is owned by someone who has not changed, does not have the nature to change, or often accompanies one's desires or wishes. While seen from the natural aspects that are owned, it can vary according to time or the influence of the surrounding environment. Human value is a value that can experience growth and development based on an agreement from humans (Ikhwan, 2013). This value will experience growth and development of superior and increasing sides. The source of this human value is sourced from rays, customary law and the surrounding natural environment (Sazali, 2017).

Rabbinic and insane values developed in the Al-Kautsar Ponorogo Children's Park are also reinforced by Noeng Muhadjir's opinion, which stresses that the function of education is to preserve human values and spiritual values. Human values are the values that grow on human beings. While the religious values are the values passed down through the Apostles revealed through the scriptures (Fadhil, 2018).

\section{Implementation of Family Involvement in Internalizing Religious Values in Children}

Based on research findings that show that the steps of family involvement in internalizing religious values in early childhood in Al-Kautsar Ponorogo Kindergarten are through the process of knowing, doing, and being. This is by the theory put forward by Ahmad Tafsir; namely internalization is an attempt to instill knowledge (understanding), can do it (doing), into the human soul (being). Therefore there are levels in internalizing values up to the human soul (person).

First, the transformation of value (knowing). The first step taken to internalize religious values in the Al-Kautsar Ponorogo Kindergarten family is to introduce knowledge. Parents instil religious values in children when at home. The contact book from the school guides the process of adding religious values in this family. The teacher writes material that is not understood by students in the contact book so that it is deepened when at home. Then parents teach the material that is the task of the teacher.

Second, Value Transactions (Doing). The second step taken to internalize religious values in the Al-Kautsar Ponorogo Kindergarten family is to familiarize children with religious values that are rabbaniyah and insaniyyah when at home under the guidance of parents. Parents guide children about the correct ablution procedures, guide children about the correct procedures for prayer, accompany the child when memorizing short letters, reading the Qur'an, memorizing daily prayers, short letters, being guided for drinking and eating while sitting, guided for charity, saying thank you and polite words, giving and apologizing when wrong, reminding to pray, and saying the thayyibah (good words). Lickona asserted that the process of transforming the value of life must be fostered through one's personality and behavior so that it becomes one with behavior (Lickona, 2003).

Third, the transinternalisation of values (being). The third step taken in internalizing religious values in the Al-Kautsar Ponorogo Kindergarten family is to transinternalize values (being) or reach the souls of children. Parents, besides conducting advice and conducting

Dinamika IImu, Volume 19(2), 2019 
parental guidance, also carry out these religious values at home. Parents set an example for their children in learning religious values. So in this way, the child will more easily absorb into his soul. This is as exemplified by the Prophet to his people. Parents give examples of good deeds or actions to children (Kementerian Pendidikan Nasional, 2010).

Example exemplifies the behavioural aspects in the form of concrete actions rather than just talking without action (Muhammad, 2010). According to Kelvin, the modelling approach, exemplary (uswah) is more appropriate to be used in character education, because the character is not knowledge, so it must be exemplified not taught. Moral behaviour is obtained in the same manner from other responses, namely through modelling and reinforcement (Ikhwan, 2019). Through modelling learning, there will be the internalization of various moral, prosocial, and other rules for good actions. Humans tend to imitate what is learned behavior. Ahmad Tafsir also pointed out that in internalizing religious values, several strategies can be carried out as follows: (1) give an example (example). (2) getting used to good things. (3) enforce discipline. (4) provide motivation and encouragement. (5) giving a gift primarily psychologically. (6) punish (maybe in the context of discipline). (7) the acculturation of religion which influences children's growth (Tafsir, 2004).

Parents use polite and polite language to their children, quarrel in front of children, when carrying children with their veil, recite prayers with their children or perform prayers in the mosque, memorize short letters and daily prayers, Read prayers before and after doing something, set an example and invite the children to practice or practice the teachings taught by the teacher at school, close the veil or veil, greet them at home, study or read the al-qur'an $b a^{\prime} d a$ maghrib, respect the older, and eat or drink while sitting. Education has three elements of achievement, the first, filling the brain's ability to emphasize the transfer of knowledge; second, incorporate positive values to foster the transfer of value; third, put in the good deeds and leave the bad (Daradjat, 2000).

The steps to internalize religious values in early childhood in Al-Kautsar Ponorogo Kindergarten also reinforced Muhaimin's opinion that there were three stages in the process of internalizing values, namely value transformation, value transactions and value transinternalisation. (1) Value Transformation, at the stage of value transformation, is carried out by educational staff in providing knowledge about good and not good. At this stage, there is an oral communication between an education worker and his student. (2) Value Transactions, at this stage of value transactions, communication is carried out between an education worker and his student who has a two-way nature of the reciprocal relationship. (3) Value Transinternalisation, at the stage of Transinternalisation this value is deeper and deeper than the value transaction. At this stage also not only done through two-way communication or reciprocal relationships but also psychological and character (Mawardi, 2011).

If the steps of internalizing religious values in early childhood are analyzed through the character development theory put forward by Lickona, the internalization process of religious values has indicated the existence of three processes of character development, namely moral knowing, moral feeling, and moral action (Lickona, 2013; Ikhwan, 2016).

First, students are taught to learn about morals (moral knowing), learn the good values of learning materials taught by teachers when at school and learning materials in the family by involving parents in the education process at home, and gain learning experiences from the practice of religious values that are applied when at school or when at home (Ikhwan, 2018a). Second, the affective domain which includes feelings of sympathy, having an attitude of caring for 
others, and compassion for others (moral feeling). Third, an activity or activities related to the desires, abilities and habits of students (moral action). The intention in question is a will that shows pride in doing good as the understanding they understand. Based on the three elements, it can be concluded that good character is driven by good knowledge from within. The relationship between the three elements, namely the concept of moral (moral knowing), moral attitude (moral feeling), and moral behaviour (moral action) shows that the concept of moral (moral knowing) gives an influence on moral attitude (moral feeling). Good attitude (moral feeling) gives an influence on moral (moral action). Moral behaviour (moral action) influences or interrelates with moral concepts (moral knowing) and moral attitude (moral feeling). Therefore, from these three elements, it can be concluded that good character is supported by good knowledge (Narvaes, 2014).

The steps to internalize religious values in early childhood, if analyzed through Bloom's Taxonomy theory, indicate the existence of three classification processes, namely the cognitive domain or domain, the affective domain or domain, and the psychomotor domain or domain (Azmi \& Halimah, 2017).

First, students are taught the knowledge of religious values (the domain or cognitive domain). This activity is carried out so that students can remember learning the material in their brain so that it can be stored in each child's memory. This element of knowledge that underlies the implementation of the next aspect. Second, the participation or participation of students in carrying out activities in schools, in this case, in the form of religious values that are rabbaniyah and insanity developed by the school. Also, students carry out activities in the form of religious values that are guided by the family, in this case, parents. Third, there is the activity of students in emulating teachers when at school and family or parents when at home. Teachers or parents give examples of activities such as eating using the right hand, entering the house using the right foot and exiting the house using the right foot, entering the bathroom using the left foot and exiting the bathroom using the left foot, and following the movements of ablution and prayer according to the movements taught by parent or teacher. This shows the existence of a guided movement of students. Then from creating a movement that becomes a habit because it has a process of following (learning) the previous movements so that the child will be reliable and able to prove their abilities.

\section{E. Conclusion}

The concept of religious values developed in early childhood, namely the values of rabbaniyah and values of insanity. Both values are manifested in various activities that exist in schools, namely in the process of learning activities, religious activities in schools, and school extracurricular activities. The steps of family involvement in internalizing ethical values in early childhood are carried out through the stages of value transformation, value transactions, value internalization, and value transcending with the development of aspects of knowing, doing, and being. The element of knowledge is done by giving knowledge to children about religious values. The point of doing is made by guiding children. The aspect of being done by providing an example to children. The three processes are not only carried out in schools but also carried out in the family with the guidance of parents. Also, in the process develops the concept of moral (moral knowing), honest attitude (good feeling), and ethical behaviour (moral behaviour). 


\section{BIBLIOGRAPHY}

Abdi, M. I. (2018). The Implementation of Character Education in Kalimantan, Indonesia: Multi Site Studies. Dinamika Ilmu, 18(2), 305-321. https://doi.org/10.21093/di.v18i2.1289

Azmi, F. \& Halimah, S. (2017). Pelaksanaan Pembimbingan Belajar Aspek Kognitif, Afektif dan Psikomotorik. AT-TAZAKKI, 1(1), 15-28.

Dagun, S. M. (2002). Psikologi Keluarga. Jakarta: PT Rineka Cipta.

Dalmeri, S. (2018). Concentration on Learning Program Development in Islamic Education. AlHayat: Journal of Islamic Education, 02(02), 1-18.

Dalyono. (2012). Psikologi Pendidikan,. Jakarta: Rineka Cipta.

Daradjat, Z. (2000). Ilmu Pendidikan Islam. Jakarta: Bumi Aksara.

Djaali. (2012). Psikologi Pendidikan. Jakarta: BumiAksara.

Endang, B. (2010). Futurologi dan phenomenologi nilai spiritual (hubungan allah, manusia, dan alam). Jurnal Visi Ilmu Pendidikan, 2(1), 241-258.

Fadhil, A. (2018). Nilai-Nilai Spritualitas dan Harmoni Beragama dalam Wirid Harian Kitab AlAurad Al-Nurâniyyah. Hayula: Indonesian Journal of Multidisciplinary Islamic Studies, 2(2), 129_ 144. https://doi.org/10.21009/hayula.002.2.03

Firdaus, S. (2012). Orientasi dan Manajemen Pendidikan Islam; Kajian Ihsan, Relevansi Konsep Khosyah dan Musyahadah. Holistik, 13(1), 1-40.

Fitriastuti, F. (2013). Pengaruh Interaksi Sosial Dalam Keluarga Dan Minat Belajar Siswa Terhadap Prestasi Belajar Siswa. OIKONOMLA - Jurnal Pendidikan Ekonomi, 2(3).

Hari, M. M. (2007). Manusia Dan Agama: Membumikan Kitab Suci. Bandung: PT. Mizan Pustaka. Harian Kompas. (2015). Komplotan Begal Yang Disebut Licik Dan Sadis Ditembak Polisi.

Hasbullah. (2000). Dasar-dasarIlmuPendidikan. Jakarta: PT. Raja Grafindopersada.

Hidayati, M. N. (2000). Ilmu alamiah dasar, ilmu sosial dasar, ilmu budaya dasar (LAD-ISD-IBD). Bandung: CV. Pustaka Setia.

Huda, M., Khoirurrijal, K., Dacholfany, M. I., Susminingsih, S., Hashim, A., Marni, N., ... Ikhwan, A. (2019). Empowering Learning Ethics Culture in Islamic Education. In Global Perspectives on Teaching and Learning Paths in Islamic Education (pp. 244-267). https://doi.org/10.4018/978-1-5225-8528-2.ch013

Ikhwan, A. (2013). Pengembangan Kurikulum Pendidikan Agama Islam (PAI). Malang: Insan Cita Press dan STAIM Tulungagung. Retrieved https:/ / scholar.google.co.id/scholar?hl=id\&as_sdt=0,5\&cluster=10168247928958272298

Ikhwan, A. (2014). Integrasi Pendidikan Islami (Nilai-Nilai Islami dalam Pembelajaran). Ta'allum: Jurnal Pendidikan Islam, 2(2), 184. Retrieved from http://ejournal.iaintulungagung.ac.id/index.php/taalum/article/view/574

Ikhwan, A. (2015). Teori Dasar Metode Studi Islam (Pembacaan atas Pemikiran Charles J. Adams dan Richard C. Martin). At-Tasyrib: Jurnal Pendidikan Islam, 1(1). Retrieved from http://ojs.stai-muarabulian.ac.id/index.php/Attasyrih/article/view/11

Ikhwan, A. (2016). Manajemen pengembangan kurikulum Keaswajaan dan Kemubammadiyahan dalam Pembentukan karakter: Studi Multikasus di Sekolah Tinggi Agama Islam Diponegoro dan Sekolah Tinggi Agama Islam Muhammadiyah Tulungagung. Universitas Islam Negeri Maulana Malik Ibrahim Malang. Retrieved from http://etheses.uin-malang.ac.id/9992/

Ikhwan, A. (2018a). Filsafat Pendidikan Islam: Memahami Prinsip Dasar. Yogyakarta: Diandra Kreatif. 
Ikhwan, A. (2018b). Penerapan Manajemen Hubungan Sekolah dan Masyarakat dalam Perspektif Islam. Al-Hayat: Journal of Islamic Education, 2(1), 1-16. Retrieved from http://alhayat.or.id/index.php/alhayat/article/view/19

Ikhwan, A. (2019). Development of Curriculum Keaswajaan ( Nahdlatul 'Ulama ) in Character Formation: In Global Perspectives on Teaching and Learning Paths in Islamic Education (pp. 92117). IGI Global. https://doi.org/10.4018/978-1-5225-8528-2.ch006

Ikhwan, A., Fahriana, A. S., Musyarapah, Mukhlis Fahruddin, M., \& Jaelani, D. I. (2019). Innovation of Islamic Education Through the Implementation of Mandatory Program Madrasah Diniyah ( Non-Formal Religious Education Institutions ) In Formal Institution. In International Conference in Life, Innovation, Change, and Knowladge (ICLICK 2018) (Vol. 203, pp. 320-323). Atlantis Press. https://doi.org/https://doi.org/10.2991/iclick-18.2019.66

Ikhwan, A., \& Fauzi, F. T. (2018). Islam and Civilization : Islam as Source of Value for Human Life. In R. Rohim, A. S. Ahmar, R. Hidayat, \& J. Simarmata (Eds.), WESTECH 2018 (p. 11). Medan: EAI: Research Meets Innovation. https://doi.org/10.4108/eai.8-122018.2283958

Jufri, J., La Fua, J., Nurlila, R U. (2018). Pendidikan Lingkungan Di Sekolah Dasar Negeri 1 Baruga Kota Kendari. At-Ta'dib, 11(2), 164-181.

Kementerian Pendidikan Nasional; Balitbang Pusat Kurikulum. (2010). Penguatan Metodologi Pembelajaran Berdasarkan Nilai-Nilai Budaya Untuk Membentuk Daya Saing Dan Karakter Bangsa.

Kementerian Pendidikan Nasional. (2010). Desain Induk Pendidikan Karakter. Jakarta: KEMENDIKNAS.

Lickona, T. (2013). Mendidik Untuk Membentuk Karakter. Jakarta: Bumi Aksara.

Lickona, T. (2003). Cep's Eleven Principles Of Efective Character Education. Wasington DC: Character Education Patnership.

Madjid, N. (2000). Masyarakat religious Membumikan Nilai-Nilai Islam Dalam Kehidupan Masyarakat. Jakarta.

Madjid, Nurcholis. (2013). Pengembangan Nilai-Nilai Islami Dalam Pembelajaran PAI di SMA. ElHikam Press.

Mansur. (2009). PendidikanAnakUsiaDiniDalam Islam. Yogyakarta: PustakaPelajar.

Mardliyah, W., Sunardi, S., Agung, L. (2018). Peran Manusia Sebagai Khalifah Allah di Muka Bumi Perspektif Ekologis dalam Ajaran Islam. Jurnal Penelitian, 12(2), 355-378.

Mawardi, I. (2011). Transinternalisasi Budaya Pendidikan Islam: Membangun Nilai Etika Sosial Dalam Pengembangan Masyarakat. HUNAFA: Jurnal Studia Islamika, 8(1), 27. https://doi.org/10.24239/jsi.v8i1.83.27-52

Muhaimin. (2016). Model Pengembangan Kurikulum \& Pembelajaran Dalam Pendidikan Islam Kontemporer. Malang: UIN Maliki Press.

Muhammad, F. H. (2010). Pendidikan Karakter: Membangun Peradaban Bangsa. Surakarta: Yuma Pustaka.

Narvaes, N. D. (2014). Pendidikan Moral Dan Karakter Terjemahan Imam Baehaqie dan Derta Sri Widowatie. Bandung: Nusa Media.

Nasution, A. (2018). Sekularitas Dan Spritualitas: Mencari Format Integrasi Ilmu Untuk Konstruksi Kurikulum Pendidikan Islam. Jurnal Tarbiyah, 25(1). https://doi.org/10.30829/tar.v25i1.243

Nugroho, I. S. (2016). Pembentukan Karakter Di Era Globalisasi Melalui Aktualisasi Iman Kepada Nabi. INSANLA : Jumal Pemikiran Alternatif Kependidikan, 21(2), 293-308. 
Nurmasari, R., Wahyono, H., \& Haryono, A. (2016). Peran Status Sosial Ekonomi Orangtua terhadap Masa Depan Anak. Jurnal Pendidikan: Teori, Penelitian, Dan Pengembangan, 11(1).

Putri, A. E., Agung, I. G., Negara, O., \& Kristiantari, M. R. (2017). Pengaruh Model Pembelajaran Kooperatif Tipe Numbered Head Together Berbasis Pendidikan Karakter. Mimbar PGSD, 5(2).

Ratnawati, D., Sarjana, U., \& Taman, W. (2016). Kontribusi Pendidikan Karakter dan Lingkungan Keluarga terhadap Soft Skill Siswa SMK. Tadris: Jurnal Keguruan Dan Ilmu Tarbiyah, 01(1), 23-32.

Sahlan, A. (2010). Mewujudkan Budaya Religius Di Sekolah. Malang: UIN-Maliki Press.

Sazali. (2017). Agama dan Pencerahan Budaya : Internalisasi Nilai-Nilai Pendidikan Agama Islam pada Budaya Masyarakat Indonesia. Jurnal Sosial Dan Humaniora, 1(2), 145-162. Retrieved from http://journal.unas.ac.id/populis/article/view/200

Setiawan, B. (2013). Al-Qur'an Sebagai Teks Terbuka (Meneguhkan Nilai Kemanusiaan Dalam Al-Qur'an). Humanika, 13(1), 65-66.

Sidiq, U., \& Ikhwan, A. (2018). Local Government Policy Regarding Mandatory Students Diniyah Takmiliyah in Indramayu Regency. KARSA: Journal of Social and Islamic Culture. https://doi.org/10.19105/karsa.v26i1.1444

Sjarkawi. (2008). Pembentukan Kepribadian Anak. Jakarta: Bumi Aksara.

Sukaimi, S. (2013). Peran Orang Tua Dalampembentukan Kepribadian Anak: Tinjauan Psikologi Perkembangan Islam. Marwah: Jurnal Perempuan, Agama Dan Jender, 12(1), 81. https://doi.org/10.24014/marwah.v12i1.515

Sukiyani, F., \& Zamroni. (2014). Pendidikan Karakter dalam Lingkungan Keluarga. Socia: Jurnal Ilmu Ilmu Sosial, 11(1), 1-20. https://doi.org/10.21831/socia.v11i1.5290

Sulton. (2016). Realitas Pendidikan Nilai Di Lingkungan Keluarga, Sekolah Dan Masyarakat. ISTAW A: Jurnal Pendidikan Islam, 1(2), 28-51.

Suparman, E. (2014). Korupsi Yudisial (Judicial Corruppon) dan KKN di Indonesia. Padjadjaran Jurnal Ilmu Hukum, 1(2), 209-227.

Supeni, S. (2015). Developing a Model of the Pancasila Character. Cakrawala Pendidikan, XXXIV(1), 118-127.

Susanti, S. (2016). Membangun Peradaban Bangsa Dengan Pendidikan Karakter. Istawa: Jurnal Pendidikan Islam, 1(2), 138-159. https://doi.org/10.24269/ijpi.v1i2.173

Syah, Muhibin. (2010). Psikologi Pendidikan Dengan Pendekatan Baru. Bandung: PT. Remaja Rosada Karya.

Syawaluddin, S. \& Iswari, M. (2014). Jurnal Konseling dan Pendidikan. Jurnal Konseling Dan Pendidikan, 2, 15-24.

Tafsir, A. (2004). Metodologi Pengajaran Agama Islam. Bandung: Remaja Rosda Karya.

Tafsir, A. (2006). Filsafat Pendidikan Islam, Integrasi Jasmani, Rohani, dan Kalbu Memanusiakan Manusia. Bandung: Remaja Rosda Karya.

Waliko, W. (2007). Konsepdakwah Rabbaniyah Dalam Perspektif Al-Qur' an. Komunika, 1(1), 30-54. https://doi.org/https://doi.org/10.24090/kom.v1i1.2007.pp30-54

Wiwinda. (2016). Hubungan Pendidikan Agama Islam dengan Tingkat Religiusitas Siswa. At Ta'lim, 15(1), 48-62.

Yusuf, Syamsu. (2011). Perkembangan Peserta Didik. Jakarta: PT. Raja Grafindo Persada. 